\title{
脳幹電位よりみた重症頭部外傷の脳幹損傷
}

\author{
西本 博・坪川 孝志・築山 節・山本 隆充 \\ 北村 守彦・片山 容一・森安 信雄

\section{Evaluation of Brain Stem Damage in Severe Head Injury by Far Field Acoustic Response} \\ Hiroshi Nishimoto, Takashi Tsubokawa, Takashi Tsukiyama, \\ Takamitsu Yamamoto, Morihiko Kitamura, \\ Yorghi Katayama and Nobuo Moriyasu \\ Depariment of Neurological Surgery, Nihon University, Tokyo 173
}

\begin{abstract}
Summary
Far field acoustic responses (FARs) were recorded at the vertex in 104 cases suffering from severe head injury. Alterations in the responses were compared with Glasgow coma scale scores, CT findings and outcome. In 30 cases, FARs elicited by bilateral monoaural stimulations and binaural stimulations were recorded for evaluation of the asymmetrical abnormalities. These results may be summarized as follows:

Two different types of alterations in the responses were recognized in the acute stage of severe head injury. These two types were (i) prolonged latency or disappearance of the 5 th waves and (ii) disappearance of the lst to 5 th waves. The former type is suggesting damage to the midbrain improved within two weeks after the trauma. In contrast, the latter type indicates the dysfunction of the pons and medulla remained. These alterations in the responses were correlated with the outcome three months after the trauma. In $73 \%$ of 22 cases whose severity were less than seven on the Glasgow coma scale, abnormalities of FARs indicating the dysfunction of the brain stem were shown. Asymmetrical abnormalities of 5 th waves were found in $30 \%$ of 30 cases suffering from severe head injury. However, this lateralization of the upper brain stem lesions by FARs were not significant for predicting the outcome three months after the trauma.

Based on these results, it was concluded that the FAR is a useful indicator and predictor concerning the function of the brain stem in patients with severe head injury.
\end{abstract}

Key words : far field acoustic response, brain stem auditory response, head injury, brain stem injury, Glasgow coma scale

I はじめに

重症頭部外鹪例の診断にCT scanが応用されるよらに なり，脳実質外血腫の有無に加えて，䌤挫稘，外傷性腷 内血腫などの脳実翼内病変の状態をより明確に捉えるこ とができるよらになっだ゚10315)，このよ5な神経放射線
学的診断法の進歩に加えて, 持続的頭蓋内圧剆定法が改 良され，より容易に頭蓋内圧のモニタリングが施行さ れ，頭蓋内病態に即応した治療方針がとられるようにな っている(11)193.

しかし，CT 診断や持続頭蓋内圧测定法を駆使して も，合併する 1 次的あるいは 2 次的な脑幹損傷の程 度

日本大学脳神経外科

[連絡先: $\overline{7} 173$ 東京都板橋区大谷口上町 30 , 日本大学脑神経外科, 西本 博]

1981年5月 1 日 受稿 
をより早期に，しかる客観的に捉えることができなけれ ば，正確な手術適応の決定や予後判定は不可能といわね ばならない，このような腷幹損傷の客観的診断法とし $\tau$, 聴性脳幹反応 (far field acoustic response, FAR) を 応用することが有用であることは，すでに Greenberg

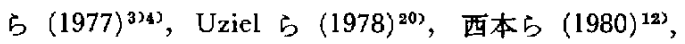
Tsubokawa ら $(1980)^{16)}$, 加我ら $(1981)^{9)}$ により報告さ れている.

FAR を媨幹損傷の客観的診断法として态用すること により，1 次的あるいは 2 次的な脳幹損稘の程度を明確 に捉えることが可能となり，才でに不可逆的な脳幹損傷 の合併する症例手術適応から除外じ，より正確な生 命予後の判定も急性期にできるよらになっている年16).

ところが，FARを重症頭部外傷に括ける脳幹損侮の 客観的診断法として応用する際に，まだいくつかの間題 点が残さ机ている，その第 1 は記録症例の選択である。 重症頭部外傷の初期治療にあたり，どの程度の重症度で あれば FAR を応用し，経時的に脳幹機能をモニタリン グすることが不可欠であるかを明確にしておく必要があ る．第 2 は，FARを用いて脳幹機能を程時的にモニタリ ングする場合，どの程度の期間はモニタリングが必要と なるかである，急性期に FAR を経時的に記録検討して みると，その所見が改善あるいは增悪する症例が多数認 められ，どの時点生で経時的䎲記録する必要があるかが 問題である，第 3 には，FARの主成分である第 II V 波 が両側の聴覚求心采の活動を反映する複合反応 ${ }^{6)}$ とされ ているにもかかわらず，刺激耳側によりその所見の異な る症例のあることである。このような場合に FAR 所見 の判定をいか化充べきかが問題となってくる。

そこで今回は，現在までの記録結果をまとめるととも に，以上の問題点についても明らかにしえたと考えるの で報告したい.

\section{II 検索対象ならびに方法}

検菜対象は，1980年6月までに日本大学脳神経外科に て治療を受けた重症頭部外傷例の5ちで，急性期より FAR を記録してある104例である。1978年12月以前の74 例については，両耳同時刺激による FAR のみを，1979 年 1 月以降の 30 例については，左右片側耳拉よび両耳同 時刺激による FAR を記録分析している，左右片側耳刺 激によるFAR を比較検討する際には，記䩮されたFAR の第 I 波の潜時，振楅などに問題のある記録例は梌索対 象上り除外した。

以上の検索対象例纪ついて，患者の臨床症状, 重症 度, CT 所見, 予後, 剖検所見などと FAR 所見との比
較検討を行っている

患者の重症度の評価は，予後判定に最適とされてい $る^{7}$ 入院時上り 6 時間後でのGlasgow coma scale (GCS) にて判定し，予後の判定は Glasgow outcome scale に従 い，外傷後 3 力月の時点で追跡調查している.

FAR は，被挨者に headphone を介して，audiogenerator（DANA JAPAN 502-A）にて作製された clich 音 ( $3 \mathrm{kHz}$ sine 波 1 周期, $80 \sim 100 \mathrm{~dB} \mathrm{SL}$ ) 左右片側招上 び敖側耳に聞かせ，導出している，導出方洗は，vertex $(\mathrm{Cz})$ と刺激側耳架 $(\mathrm{Ai})$ ，および vertex $(\mathrm{Cz})$ と刺激対側 耳桑 (Ac) の 2 種類を用いて同時仪記録している。導出 された FAR は增幅後, 分析時間 $10 \sim 25 \mathrm{~ms}$ とし，2,000 回平均加算し，その結果を $\mathrm{X}-\mathrm{Y}$ recorder にて記録した。

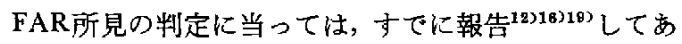
る各波の正常值に基ついて判定し，第V波の振幅は第 I 波との振幅比が逆転した場合を第 V波の振幅低下として いる.

\section{II 検 索結 果}

\section{1. 重症頭部外俉例における FAR 所見と生命予後との 関連}

両側耳同時刺激による FAR を記録してある74例につ いて，そのFAR 所見と生命予後との関連をみたのが Table 1 である。重症頭部外傷74例のらちで，FAR上異 常が認められた症例は41例存在した。この5ちで，CT 招上び剖険所見より primary brain stem injury と考えら れる症例が 3 例，その他は secondary brain stem injuryで ある. Primary brain stem injury と考えられる 3 症例で は，FARは第 $\mathrm{I} \sim \mathrm{V}$ 波が消失して扔り，すべて死亡して いる. Secondary brain stem injury 例にお汀る FAR所見 は，3種類の pattern が認められ，FAR上の異常が第 V 波のみに限局している症例では，その生邻予後注良好で 南った．第吕 V V波が消失し，第 I， II波のみが残存し ていた 2 例でも，同様にその生命予後は不良であった。 しかし，後頭蓋窝急性硬膜外血腫の 1 例で, 初回記録時 に第 I，II波のみ残存していた FAR が，1 週間後には 第吕，IV，V波が回復した症例があり，その生命予後は 良好であった．第I～V波がすでに消失して扔り，下部 脳幹までの障害が証明された症例では，FARを経時的に 記録しても所見が改善することはなく，すべて死亡する か，植物状的心移行した。

\section{GCS 亡FAR 所見との関連}

患者がどの程度の重症度であれば FAR をモニタリン グすることが不可欠であるかを検討するために，重症度 あるいは予後判定法として高く評洒されている GCS と 
Table 1 Alterations in the FARs recorded from patients with severe head injury

\begin{tabular}{|c|c|c|c|c|c|}
\hline \multirow[b]{2}{*}{ FAR } & \multirow[b]{2}{*}{ Cases } & \multicolumn{2}{|c|}{ Brain stem injury } & \multicolumn{2}{|c|}{ Prognosis } \\
\hline & & Primary & Secondary & Good (survived) & Vegetative or dead \\
\hline Normal & 33 & - & - & 33 & 一 \\
\hline $\begin{array}{l}\text { Prolongation of latency or } \\
\text { disappearance of } 5 \text { th wave }\end{array}$ & 14 & - & 14 & 11 & 3 \\
\hline Disappearance of $3 \mathrm{rd}-5$ th waves & 2 & - & 2 & - & 2 \\
\hline Disappearance of ls $t-5$ th waves & 25 & 3 & 22 & - & 25 \\
\hline
\end{tabular}

Table 2 Incidence of abnormalities in the FARs in relation to Glasgow coma scale scores

\begin{tabular}{lcccc}
\hline \multirow{2}{*}{ FAR } & \multicolumn{3}{c}{ GCS } \\
\cline { 2 - 4 } & $3 \sim 4$ & $5 \sim 7$ & $8 \sim 10$ \\
\hline Normal & 1 & 5 & 6 \\
$\begin{array}{l}\text { Prolongation of latency or } \\
\text { disappearance of 5th wave }\end{array}$ & 4 & 7 & 2 \\
$\begin{array}{l}\text { Disappearance of 3rd-5th } \\
\text { waves or lst-5th waves }\end{array}$ & 5 & - & - \\
\hline
\end{tabular}

FAR所見上を，入院時より 6 時間後に比較検討した. 入 院時より 6 時間後の GCS の記載が明確な30例を選び出 し，検討した結果が Table 2 である。30例の GCS の内 訳恃, GCS $3 \sim 4$ を示すもの10例， $5 \sim 7$ を示寸bの12 例，8〜10走すbのが8例であった．予後不良とさ れている 7 以下を示した症例は 30 例中 $73 \%$ であった. GCS 8〜10の症例では，FAR が正常であったのが 6 例， 第V波のみの異常が䕀められた例が 2 例である. GCS 5 $\sim 7$ の症例では，FAR所見は正常 5 例，第V波のみの異 常が 7 例に認められた. GCSが3〜4となると，第V波 のみの異常が 4 例，第 I，II，III波まで異常のある例が 5 例であり，正常であったものは1例のみであった。

なおこれらの症例に打汀る FAR の経時的記録結果 をみと，GCS 7 以下の症例では，6時間後の FAR 所 見の異常が第V波に限局していたり，正常であっても， 3 日間以内に FAR 上下部遒幹までに障害が波及する例 が多かった。

\section{FAR の経時的記録結果}

第 1 病日に記録されたFAR 上，第 I $\sim$ V波が消失し ていた症例では，释時的に記録しても第V波が出現した 症例はなく，改善されても第I，卭波のみであった。

また第 1 病日に FAR 上の異常が第V波に限局してお り，経過に従ってFAR 所見の増悪する症例では，大部 分が3 日以内に第 $\mathrm{I} \sim \mathrm{V}$ 波までが消失するに至った。

経過に徒ってFAR 所見の改善される症例は, 第 1 病 日に記録された FAR 上第V波の潜時延镸のみを認める

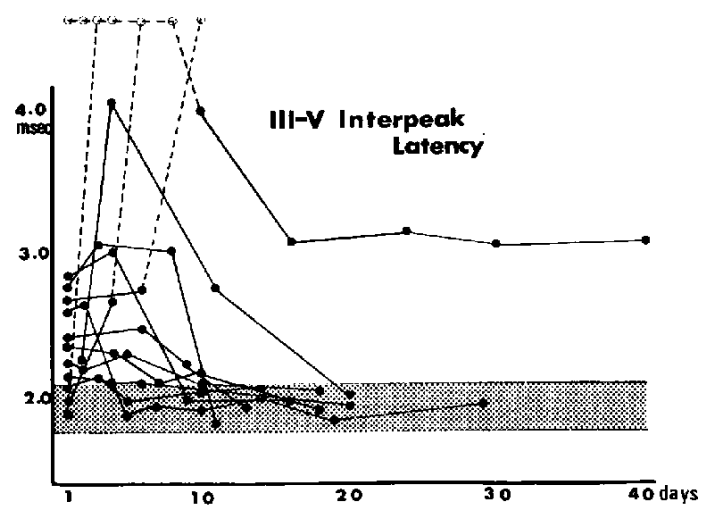

Fig. 1 Changes of III-V interpeak latency in the FARs for 1 to 40 days after neurosurgical treatment. Three different types of latency changes are demonstrated. In most cases illustrated in this figure, III-V interpeak latencies are normalized within 10 days.

例であった（Fig. 1).これらの症例にて経時的に記録し た結果を，III-V interpeak latency を指標として検討し てみると，大部分の症例では第10病日前後で正常化して いた，その際に，意識障害の改善と FAR 所見の改善と 在対比してみると，意識障害の改善に先立って FAR が 正常化していた.

\section{4. 刺澈耳側により FAR 所見の異なる症例}

左右片側刺激および両耳同時刺激によるFAR を記録 してある30症例において，FAR上の左右差について検討 した，その際に，FARの第 I，II波の潜時や振幅に正常 範囲以上の左右差のある記録は除外している。

第 I， II波の潜時や振幅に左右差がないにもかかわら す，第III，V波の潜時や第V波の振幅に左右差のある FAR が，释過中に 1 回以上記録された症例は30例中 10 例 $(33 \%)$ に諗められた。 その左右差所見としては，一側 耳刺激時のみに第V波の消失や振幅低下が認的られた例 が10例中 5 例, 一側耳刺激時のみに III-V interpeak latency の延長があった例が 10例中 4 例，一側耳刺激時の みに第III，IV，V波が消失していた例が10例中 1 例あっ 


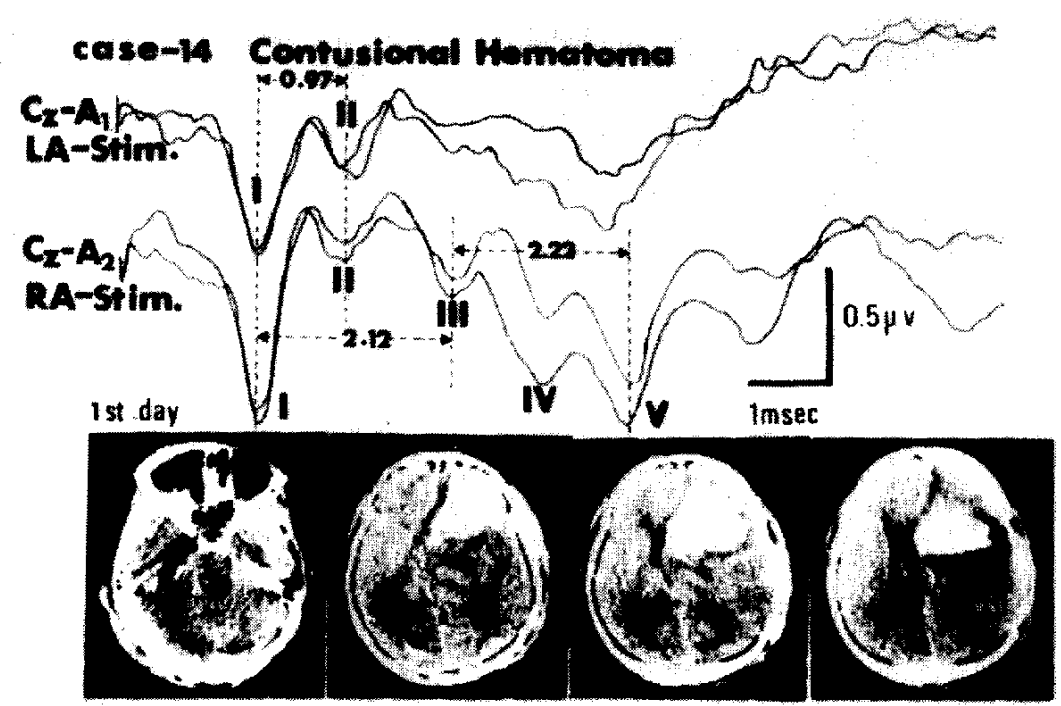

Fig. 2 Examples of asymmetrical abnormalities in the FAR recorded in a patient with contusional hematoma. Note that 3 rd to 5 th waves are absent in the FAR by left-monoaural stimulation, but all waves are normally present in the FAR by right-monoaural stimulation. FARs demonstrated in this figure were recorded on the lst day. Left and right-monoaural stimulations were at $100 \mathrm{~dB}$ SL.

Table 3 Relationship between abnormalities in the FARs and the outcome of severe head injury

\begin{tabular}{|c|c|c|c|c|c|c|c|c|c|c|c|}
\hline \multirow[b]{2}{*}{ FAR } & \multicolumn{2}{|c|}{$\begin{array}{l}\text { Good } \\
\text { recovery }\end{array}$} & \multicolumn{2}{|c|}{$\begin{array}{l}\text { Moderate } \\
\text { disability }\end{array}$} & \multicolumn{2}{|c|}{$\begin{array}{l}\text { Severe } \\
\text { disability }\end{array}$} & \multicolumn{2}{|c|}{ Vegetative } & \multicolumn{2}{|c|}{ Dead } & \multirow[b]{2}{*}{ Total } \\
\hline & No. & $\%$ & No. & $\%$ & No. & $\%$ & No. & $\%$ & No. & $\%$ & \\
\hline $\begin{array}{l}\text { Asymmetrical abnormalities }(-) \\
\text { Normal }\end{array}$ & 4 & 57 & 1 & 14 & 2 & 29 & - & & - & & 7 \\
\hline $\begin{array}{l}\text { Prolongation of latency or } \\
\text { disappearance of } 5 \text { th wave }\end{array}$ & 3 & 43 & 2 & 29 & 1 & 14 & 1 & 14 & - & & 7 \\
\hline Disappearance of lst -5 th waves & $\longrightarrow$ & & - & & - & & - & & 6 & 100 & 6 \\
\hline \multicolumn{12}{|l|}{ Asymmetrical abnormalities $(+)$} \\
\hline $\begin{array}{l}\text { Prolongation of latency or } \\
\text { disappearance of } 5 \text { th wave }\end{array}$ & 3 & 33 & 2 & 22 & 2 & 22 & 1 & 11 & 1 & 11 & 9 \\
\hline Disappearance of $3 \mathrm{rd}-5$ th waves & - & & - & & 1 & 100 & - & & - & & 1 \\
\hline
\end{tabular}

た. したがって，一侧耳刺激時にのみ第V波に異常のあ る例が大部分であるといえる。

Fig. 2 注 contusional hematomaの症例で, 第 1 病日に 記録された FAR 所見である.FAR記録時の GCS は 6 であった，左耳刺激時の FAR では，第 I， II 波のみ が認められ，第III〜V波が消失していた，右耳刺激時の FAR では第 I 〜 V波が認められ，その潜時には異常が 認められなかった。本症例の生命予後は良好であった が機能予後は覀く, 見当識障害, 左片麻㾝などを残し た.

次にこのような一側耳を刺激したときのみに第V波 に異常の認められる症例と，両耳を同時に刺激しても第 V波に異常の諗的らる症例との間で, 3 力月後の生命
予後に差が存在するかどらかを検討してみた。 その結果 は Table 3 に示すよ5に，両群の間で生命予後に有意の 差は認めがたく，ほぼ同様であった（Table 3)。

\section{V 考按}

\section{1. 重症頭部外侮における FAR 所見}

重症頭部外傷に持けるFAR 所見は, 正常, 第V波の みの異常，第 $\mathrm{I} \sim \mathrm{V}$ 波あるW第 II V 波の消失と， 3 型に分類することができる。こ狆らの FAR 所見の示す

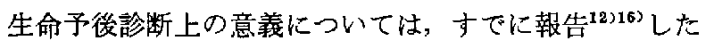
ごとくである。しかし，後頭蓋窝血腫例については，天 幕上病変例とは異なる経過が FAR 上認められ，FAR 第 I，II波のみが認められる場合でも，経時的に記銶す 
ると，第而 V波が改善される例が存在した。このこ と法，高血圧性脳出血飞招いて，putaminal hemorrhage と小慆出血とでは，FAR に及ぼす障害 patternが異なる ことが報告 ${ }^{17}$ されている事実とよく一致していた．した がって, 後頭蓋窝血腫例については, 今後別に検討を要 すると考える。

\section{GGS Ł FAR 所見}

GCS と FAR所見とを比較検討してみると， GCS が 7 以下となると FAR 上る譄幹損賃を合併している症例 が多く，下部脑幹までの損傷が存在している症例はすべ てGCS 3〜4 を示していた. GCS 3〜4を示す症例で は，その予後不良因子として，非可逆的な稱幹損傷が大 きく関与していると考えられる。史た GCS が5〜7を 示す症例では，FAR所見上，上部脑幹損傷が認められる 例が多く，この脳幹損傷がさらに進行するかどうかを， FAR をモニタリングして提えることが重要である。

したがって，呼吸や㨁環に対する処置が施され，shock などの影響が取り除かれた段階で，GCS 7 以下を示す症 例では，治療方針の決定上 FAR を記録分析することが 不可欠であり，すでに下部脳幹までの損傷を合併してい る症例は手術適応から除外すべきである。

\section{FAR の経時的モニタリング}

FAR 在経時的に記録した結果よりみると，FAR 所見 が増覀する場合は 3 日以内に, 改善される場合には第 10 病日前後で正常化する症例が多いので, 最低10日から 2 週閒のモニタリングをする必要があると考える. 改善さ れてくる場合には，意識障害などの臨床症状に先立って 正常化するので, 上り早期に生命予後を判定することが 可能である.

\section{4. 刺激耳側により FAR 所見の異なる症例の形断}

聴賞求心路には非交及性拉上び交叉性の線維が劣り, FAR の第 II V 波屿その両者の複合反心志考えられる にもかかからず，細幹部腫瘍などの脑幹の一部に限局し た病変では，刺激耳側により左右差の認められることが 報告されている ${ }^{19)}$. 今回重症頭部外榎例に扝いて検索し てみると，第 I， II波の潜時や振幅左右差がないにも かかわらず，第V波に左右差の琶められる例が $33 \%$ 亿存 在した.

このような左右差を検討するに当っては, 各波の反応 闌値が問題となってくるが，第 I， II 波には左右差が認 められなくても，第V波注左右差の出現することがあ るので, 反応閥值による差とは考えられない，

Achor ら $(1980)^{12}$ は脳幹の損稘の局在によっては左右 差の出現することを㬰験的に証明しており，Buchwald ら $(1975)^{22}$ は，第V波注として交丑性線維により活動
した下丘の反応であるとしている，したがって，上部媵 幹の損稘の局在によっては，刺激耳側により FAR の第 V波に左右差の出現することが考えられる。

しかし, Thornton (1975) ${ }^{18)} ら$, Hashimoto $ら(1979)^{5)}$, Shin ら (1981) 14) の指摘するような記録側による左右 差所見は，今回の重症頭部外傷例に打ける検討では諗め られなかった。

以上の上らな刺激側に上る第V波の左右差のある症例 とない症例とで，その生命予後を比較検討した結果で は, 両者に有意差は認心られなかった。したがって, 重 症頭部外甥における媨幹損傷の客観的診断法として FA Rを応用する際には, 脑幹部腫瘍の診断に用いる場合と 異なり，両耳刺激時のFAR のみでも十分診断的佂值が あると考えられる。

\section{$\mathrm{V}$ 結 語}

1. 重症頭部外傷例に括訬る FAR 所見は，正常，第 $\mathrm{V}$ 波のみの異常，第 $\mathrm{I} \sim \mathrm{V}$ 波あるいは第 $\mathrm{II} \sim \mathrm{V}$ 波の消失 と3型に分類することができ，これらのFAR 所見は， その患者の生命予後と密接な関連が認められた。

2. 入院後 6 時間目での GCS が 7 以下を示す症例で は，FARを記録分析し，腷幹損稘の合併の有無扔よびそ の経過を提えることが治療方針の決定上有用である。

3. 重症頭部外傷例においては，第10病日前後をで， 経時的に FAR を記録分析する必要がある.

4. FAR を重症頭部外傷に抢ける脳幹損傷の客観的 診断法として応用する際には，脑幹部腫煌の診断に用い る場合と異なり，両側耳同時刺激によるFAR のみで十 分診断的価值があると考えられる。

以上の事実上り，重症頭部外傷における脑幹損傷の客 観的骖断法，生命予後の判定法として，FARを臨床応用 することが有用であると考えられるので報告した，

本論文の要旨は，第39回日本檤神経外科学会総会 （1980，会沢）に招いて発表した。

\section{文献}

1) Achor, J. \& Starr, A.: Auditory brainstem responses in the cat. II Effects of lesions. Electroencephalogr Clin Neurophysiol 48: 174-190, 1980

2) Buchwald, J. S. \& Hung, C. M.: Far-field acoustic responsc; Origins in the cat. Science 189: 382-384, 1975

3) Greenberg, R. P., Mayer, D. J. Becker, D. P., et al.: Evaluation of brain function in severe human head trauma with multimodality 
evoked potentials. Part I: Evoked brain-injury potentials, methods and analysis. $J$ Neurosurg 47: $150-162,1977$

4) Greenberg, R. P., Mayer, D. J., Becker, D. P., et al.: Evaluation of brain function in severe head trauma with multimodality evoked potentials. Part II: Localization of brain dysfunction and correlation with post traumatic neurological conditions. $J$ Neurosurg 45 : 515-524, 1977

5) Нashimoto, I., Ishiyama, Y. \& Tozuka, G.: Bilaterary recorded brainstem auditory evoked responses. Their asymmetric abnormalities and lesions of the brainstem. Arch Neurol 36: 161-167, 1979

6)市川銀一郎：聴性媨幹反応の成因, 神経研究 の進歩23: 308-335，1979

7) Jennett, B., Teasdale, G., Gal.braith, S., et al.: Severe head injuries in three countries. $J$ Neurol Neurosurg Psychiatry 40: 291-298, 1977

8) 北村守彦, 营原武仁, 田熊能方 他: 遅 発性 外稘性脳血腫一その診断基準 と手術適応一。目 本多害医学会雑誌（投稿中）

9) 加我君孝, 長井犬二, 高森晶裕 他: 急性脳 損稘による意識障害時の聴性这幹反忘と温度眼 振反応. 脳神経33：171-179, 1981

10) Lanksch, W., Grumme, T. \& Kazner, E.: Computed tomography in head injuries. Springer-Verlag, Berlin, 1979

11) Miller, J. D., Becker, D. P., WARD, J. D., et al.: Significant of intracranial hypertension in severe head injury. $J$ Neturosurg 47: 503-516, 1977

12）西本 博, 坪川孝志, 山本隆充 他：重 症 頭

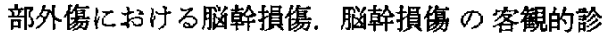
断法としての Far Field Acoustic Response の意 義. 这外 $8: 355-362 ， 1980$

13) Papo, I., Caruselli, G., Luong, A., et al.: Traumatic cerebral mass lesions; Correlations between clinical, intracranial pressure and computed tomographic data. Neurosurg 7: 337 346,1980

14) Shin, J., Kubo, T., Soyer, A., et al.: Lateralization of brainstem lesions by brainstem auditory evoked potentials. Neurol 31: 14-18, 1981

15）坪川孝志，片山容一，上野裕壱 他：外傷性 脑内血腫の出血機序一とくに遅発性血腫につい て一。神経外稘 3：147-153，1980

16) Tsubokawa, T., Nishimoto, H., Yamamoto, T., et al.: Assessment of brainstem damage by the auditory brainstem response in acute severe head injury. $J$ Neurol Neurosurg Psychiatry 43: 1005-1011, 1980

17）坪川孝志，策山 節，上野裕壱 他：高血圧 性媨出血に扔ける脳幹電位の桱討一とくにputaminal hemorrhage と小脳出血の差異についてー。 第 6 回日本媨卒中学会総会, 1981

18) Thornton, A.: Bilaterally recorded early acoustic responses. Scand Audiol 4: 173-181, 1975

19) 山本隆充, 北村守彦, 片山容一 他: Far Field Acoustic Response の腹幹腫瘍に対寸る診断価值 臨床膊波23:105-113，1981

20) Uziel, A. \& Benezech, J.: Auditory brainstem responses in comatose patients. Relationship with brain-stem reflexes and level of coma. Electroencephalogr Clin Neurophysiol 45: 515-524, 1978 